\title{
Conservation Officers: A Force Multiplier for Homeland Security
}

\author{
Jeremy G. Carter, Ph.D. ${ }^{1}$ \\ Indiana University - Purdue University Indianapolis \\ Meredith L. Gore, Ph.D. \\ Michigan State University
}

\begin{abstract}
Today's law enforcement officers - both conservation and police - find themselves adapting to an emerging and dynamic threat environment. Policies and practices aimed at the prevention of threats have focused primarily on federal, state, and local police agencies. At a time when terrorists, extremists, and activists have begun to widen their array of attack methods, collaboration across all sectors of law enforcement becomes essential. More specifically, an increased vulnerability to biological threats has not been met by steps to prevent or mitigate these threats. Conservation officers have a unique and integral role to enhance homeland security efforts given their day-to-day operations and interactions with the community, especially rural America. This article will discuss the role of conservation officers as it relates to homeland security - a significant conceptual component to research and practice that has largely been ignored by both academics and professionals. The integration of conservation officers into the proactive information sharing environment will be discussed to strengthen a culture of information sharing as it pertains to an "all-threats, all-hazards" philosophy and to enhance national security awareness. Moreover, this article will challenge the traditional range of threats associated with biological terrorism by providing an illustrative case study.
\end{abstract}

Keywords: Homeland security; Intelligence-led policing; Threat prevention; Biological terrorism; Rural threat prevention

Carter, J. G. \& Gore, M. (2013). Conservation officers: A force multiplier for homeland security. Journal of Applied Security Research, 8(3), 285-307.

\footnotetext{
${ }^{1}$ Author Correspondence: 801 W. Michigan Street, Indianapolis, IN 46202, P: (317) 274-4170, carterjg@iupui.edu
} 


\section{Conservation Officers: A Force Multiplier for Homeland Security}

\section{INTRODUCTION}

The terrorist attacks of September 11, 2001 (referred to hereafter as 9/11) brought about a new perspective for law enforcement - one based on threats as well as crimes. Of course, law enforcement agencies were cognizant of threats prior to $9 / 11$, but the types of threats and methods employed have since changed dramatically. The emphasis of homeland security intelligence has sought to assist the law enforcement community in developing a level of situational awareness and preparedness for law enforcement personnel. Threat methods have evolved from varying types of bombs and firearms to sophisticated types of biological agents and even species. ${ }^{1}$ Biological terrorism has thus far been largely examined in the context of weapons of mass destruction (Shea, 2004; Kronin, 2003), psychological terrorism (Crelinston, 1999; Parachini, 2001), and emergency management (Rotz et al., 2002; Waeckerle, 2000). However, the emergence of new biological threat methods has created an environment in which law enforcement must rely on more than technological hardware in attempts to detect such threats. Prevention and mitigation of such threats can be achieved through increased collaboration via information sharing practices among conservation officers, police officers, and the community.

Building from the information sharing practices established in state and local policing, specifically law enforcement intelligence, we propose these same practices should be applied by conservation officers in their efforts to prevent and mitigate biological terrorism threats as well as environmental crimes. The practices emphasized in this discussion are informal and thus require minimal resource commitment yet simultaneously yield significant prevention results as well as professional collaboration. Homeland security efforts are in a position to capitalize on an existing rural American infrastructure already established by conservation officers throughout the United States. Such an approach could enhance existing homeland security preparedness and prevention and is long overdue as conservation officers continue to receive different training and mission mandates than their police counterparts. This difference is likely rooted in the assumption that combating terrorism and other threats is outside the purview of conservation officers. This could not be further from the case. By developing training programs and revising mission mandates of conservation officers, the prevention and preparedness capability for U.S. homeland security can be enhanced.

\section{IMPACT OF CONSERVATION OFFICERS FOR HOMELAND SECURITY}

There is no agreed upon definition of what exactly constitutes a conservation officer and their duties vary from state to state. In most states, conservation officers are considered state law enforcement officers and have broad law enforcement authority. For purposes of this discussion, the term "conservation officer" refers to any personnel, whether they be employed by the state, county, municipality, or even privately contracted, who is responsible for the enforcement of violations against natural resources and whose primary operational jurisdiction is located in rural areas outside the normal patrol or day-to-day activity of state or local police. The authors recognize that many conservation officers are responsible for jurisdictions within populous areas 
and present discussion is not intended to overlook these officers - in fact, the issues to be discussed are applicable to these officers as well. However, these populous areas are likely to have multiple law enforcement entities (sheriffs, municipal police, state police, etc.) and have more well-established mechanisms for sharing threat-related information. As such, populous areas stand to benefit from the formal integration of conservation officers into the homeland security mission, but such a benefit is likely to be significantly greater in rural areas where the density of law enforcement presence is minimal.

Though instances do exist where conservation departments have acknowledged their roles in homeland security prevention and preparedness (for example see the North East Conservation Law Enforcement Chiefs Association, 2013), these instances are the exception rather than the rule. As homeland security roles vary across state and local law enforcement agencies (Schafer et al, 2009), the same holds true for conversation agencies. While there has been no research to date examining the extent to which type of assignments conservation officers are tasked, it is believed most conservation departments facilitate the homeland security mission primarily through the patrol of waterways (especially those that are adjacent to a public utility such as a hydroelectric dam) and assisting the U.S. Coast Guard (for example see State of Connecticut, 2013). Of the limited research to date on conservation officers' duties and assignments, a consistent them has been that conservation officers are becoming increasingly responsible for enforcement beyond wildlife and natural resource-related violations. Such expanded responsibilities included, but are not limited to, drug and alcohol offenses, stolen firearms, stolen recreational vehicles, and subjects with outstanding warrants (Eliason, 2007). Furthermore, it has been found that conservation officers are becoming responsible for providing assistance to other police and law enforcement agencies and apprehending criminal suspects and escaped convicts (Falcone, 2004). These tasks go beyond the traditional purview of conservation officers and, when coupled with broad law enforcement jurisdiction that many conservation officers maintain, shift conservation officers closer to state and local police along the law enforcement continuum. Currently, the role of conservation officers in homeland security is largely concentrated on protecting waterways and shorelines. During their normal patrols, conservation officers can encounter illicit activities connected with threats to homeland security - such as discovering a site to grow marijuana that is being worked by illegal aliens with potential ties to drug smuggling on the southwest U.S. - Mexico border. Sometimes, conservation officers are the individuals who are the first to identify members of such criminal networks and often times have broader risk implications (Gore, 2011).

The integration of conservation officers into the homeland security framework is similar to current steps being taken within the public health sector. In an attempt to have adequate early warning systems as well as improved communication of health-related information that may have implications for the broader U.S. population, public health offices and personnel are being formally connected with state and regional fusion centers to enhance the sharing of health-related information (Carter and Rip, Online First). In theory, and hopefully in practice when such capacities become fully operational, the awareness and information sharing capability of public health personnel will facilitate possible threat information to state and local law enforcement. While the notion of public health notifying law enforcement of possible health threats has occurred before, it has traditionally operated on a reactionary basis. The current model allows public health personnel to provide information that is indicative of an emerging, or possible, threat before the threat actually reaches fruition. This same approach should be employed using conservation officers. As currently structured, conservation officers report information to state 
and local law enforcement after an incident has occurred which they believe will be of interest to their state and local law enforcement partners (such as finding drug growing on a mountainside or a methamphetamine lab in a cabin). However, given a lack of conservation officers included in post-9/11 law enforcement training programs and initiatives as compared to traditional state and local law enforcement as a result of their legislative jurisdiction to focus on violations involving natural resources, it is reasonable to assume a proactive information sharing process do not currently exist with the majority of conservation entities. This is troubling given the significant presence conservation officers have in the United States.

Approximately 95\% of the United States is considered to be a rural environment (U.S. Census Bureau, 2002) - the type of areas in which conservation officers spend more time patrolling than perhaps any other law enforcement agency. As such, conservation officers are in a unique position to strengthen homeland security initiatives by nature of their role in the criminal justice system. Tasked with enforcement responsibilities of crimes and violations typically found in areas of low human population density, especially rural America, conservation officers are in a position to strengthen information sharing and community awareness in areas of the United States that typically do not receive concentrated or dedicated homeland securityrelated attention as a result of their location not being within the proximity of an urban area. A significant portion of preventive and preparedness homeland security capabilities in the U.S. are driven by funding from the Urban Area Security Initiative (UASI) which relies on a risk formula to calculate preparedness expenditures. The factors considered for this formula include population, potential targets, and vulnerability - thus making it impossible for rural areas to receive much, if any, preparedness funding for training and awareness programs. As a result of these funding constraints, the focus of preventive and preparedness efforts are on urban areas due to human population density and the number of potential terrorist targets as identified in the Target Capabilities List mentioned previously and not rural America - creating a gap in homeland security capabilities. This discussion could be further extended to United States Park Police as they are commonly tasked to protect monuments (e.g., Mount Rushmore) and natural features (e.g. Niagara Falls) that are common destinations for tourists and hold high symbolic value - two significant components weighed by terrorists when selecting potential targets (Damphousse et al., 2003). However, given space considerations, the discussion throughout this article will focus on state and local conservation officers. By utilizing informal information sharing practices and partnerships with local communities and businesses, conservation officers can strengthen the homeland security gap in rural America.

\section{Utilizing Citizens of Rural Areas as Sources of Information}

The reliance on American citizens for purposes of gathering raw information to be included in the intelligence cycle is emphasized within HSPD-8. In an effort to enhance national preparedness, HSPD-8 designates the importance of information sharing and collaboration to enable effective prevention, protection, response, and recovery activities; specifically noting that “...effective terrorism prevention, protection, response, and recovery efforts depend on timely and accurate information" and that this is effort is most likely achieved through "collecting, blending, analyzing, and evaluating relevant information from a broad array of sources on a continual basis," (U.S. Department of Homeland Security, 2005, 13).

More specifically, the U.S. is comprised of an already established information sharing and educational network known as conservation districts. This network represents 2,946 local conservation districts $^{2}$ (National Association of Conservation Districts, 2012). Though these 
districts were created for the purpose of strengthening natural resources across the U.S., they represent a formal infrastructure already in existence that provides unique education and training for citizens - such as land management and hunter education. These seminars are often delivered in collaboration with conservation officers in the local community. Through these established educational mechanisms, conservation officers could provide a community awareness seminar on suspicious activity reporting, signs of terrorism planning, biological terrorism, and criminal behavior. Such programs could be implemented at minimal or no cost to taxpayers or additional strain on department budgets. Many of these threat-based training materials are accessible at no cost to government agencies from the U.S. Department of Justice and the Office for Community Oriented Policing Service. Information received from community members as a result of these educational seminars could be shared with an intelligence liaison officer or state fusion center. Through this approach, conservation officers and their daily interactions with rural America could be leveraged by state and local law enforcement as a force multiplier. For purposes of this discussion, rural America is a general reference to geographic areas of the U.S. which are primarily low in population density and typically receive less formal attention and resources with respect to homeland security. The ratio of conservation officers to traditional law enforcement personnel is higher than would be found in more populated areas of the U.S. - simply given the business and recreational nature of these areas.

Moreover, there is currently a shortcoming with respect to the level of homeland security preparedness among rural American areas. Specifically, rural area residents are reported to believe the terror threat in rural areas to be minimal, yet rural communities have expressed a desire to be formally educated regarding potential threats (Eller, 2010). As it has been discussed, conservation districts could provide information and training to their constituents in the course of the duties they already provide and the consistent contacts they have with farmers, ranchers, and large private landowners in remote areas. These persons could participate in a formal program to exchange information gathered through a suspicious activity reporting function. Furthermore, conservation officers stand to impact rural communities by educating the community about dangerous conditions or hazardous materials potentially located on or around their property (Eller, 2010). Ranchers and farmers typically employ the use of pesticides (e.g. ammonium nitrate) and herbicides during the course of their seasonal farming activities and not all have the most current information or capacity to use, dispose, or secure those materials safely.

The effectiveness of intelligence relies on the collection and analysis of raw information. Information is collected from the environments that agencies wish to develop an understanding of what potential threats and/or problems may exist within the environment. The number of environments within the United States that do not have a conservation officer component are severely limited and thus the number of environments which stand to benefit from information collected via conservation officers is paramount. If all potential information from an environment is not integrated into the intelligence process, it cannot be considered when developing prevention and preparedness responses. As such, law enforcement organizations are left with an incomplete threat picture and the probability of identifying threats before they reach fruition is diminished. 


\section{LAW ENFORCEMENT INTELLIGENCE}

As a result of the events on 9/11, American law enforcement is currently experiencing a shift in policing philosophies. Building on the foundations of community policing (Carter \& Carter, 2009; McGarrell et al, 2007), intelligence-led policing has emerged as the most promising philosophy to date (Ratcliffe, 2008). The underlying intent of intelligence-led policing is to create a policing organization that utilizes intelligence to influence strategic planning for the allocation of resources in order to have the greatest impact on crime in the most effective and efficient manner possible. Moreover, intelligence-led policing is designed to achieve this through the analysis of raw information for purposes of identifying precursors to threats and crime. Thus, intelligence-led policing mitigates crimes and threats by removing the conditions that facilitate crimes and threats. Even though the management and sharing of intelligence is regulated via specific guidelines and laws, ${ }^{3}$ intelligence largely relies on informalities and rapport between persons (Weiss, 1998). The informal aspect of intelligence-led policing is often found in the context of community partnerships, professional friendships and even personal relationships and the social networks they create. These contexts provide a significant amount of the raw information that is moved into the intelligence process. The intelligence process is the systematic, scientific, and logical methodology to comprehensively understand information by which actionable intelligence is the result (Carter, 2009).

\section{Intelligence-Led Policing}

Intelligence-led policing is designed as a mechanism for information sharing both within law enforcement agencies and between all members of the community. The concept of intelligence-led policing aids law enforcement agencies in identifying threats and developing responses to prevent those threats from reaching fruition in America's communities (International Association of Chiefs of Police, 2002). Despite an increased demand for information sharing partnerships among agencies there remains a common misunderstanding of how this will be achieved and which agencies or organizations must be active members of this process (McGarrell et al., 2007). Although the adoption of best practices for sharing homeland security intelligence is a critical component of intelligence-led policing - and thus is acknowledged here - we focus our discussion on the informal practices of information sharing among law enforcement agencies, as well as their communities, and how this information can be used to prevent threats rather than the adoption of intelligence-led policing as a fully integrated operational philosophy by conservation agencies.

There is no universally accepted definition of intelligence-led policing, although the components of most definitions are similar. The Bureau of Justice Assistance (BJA) produced an unpublished memorandum which was intended to guide the solicitation and review of violence reduction grants using intelligence-led policing processes (U.S. Department of Justice, 2007). The conceptual foundation of intelligence-led policing provided in this memorandum was articulated as building on the best practices of problem-oriented policing and CompStat and applying these principles to a threat-based environment. In the document, BJA stated, "intelligence-led policing can be defined as a collaborative law enforcement approach combining problem-solving policing and information sharing...(U.S. Department of Justice, 2007, p.1).” Building on this conceptual foundation, Carter and Carter (2009) provided an operational definition of intelligence-led policing as: 
"The collection and analysis of information related to crime and conditions that contribute to crime, resulting in an actionable intelligence product intended to aid law enforcement in developing tactical responses to threats and/or strategic planning related to emerging or changing threats (p.317)."

A critical component of this definition is the emphasis of collecting raw information that feeds the intelligence process and information sharing. Collection should be focused to identify and understand threats that emerge within a jurisdiction. Within the context of applying this practice to conservation officers, the focus of information collection should be determined by the chief decision maker or the executive of the organization. This individual will define information collection requirements based on information received from both officers and citizens in the form of suspicious activity reports (SARs).

The intelligence-led policing philosophy relies on a significant analytic component - or effective problem solving skills. It relies on deductive and inductive reasoning to define requirements and forecast threats (Ratcliffe, 2008). Analysis may be quantitative, notably for strategic analysis, but it is frequently qualitative for both tactical and strategic analysis. Since intelligence-led policing focuses on threats, it becomes essential to identify variables within a community and the surrounding region that support the generation and maturation of threats. Gathering information about these variables is vital to be included in the intelligence cycle. More specifically, variables attributing to threats can include on-going criminal activity, trends of new or emerging criminal activity, and presence of extremist or activist groups. The information collected must provide insight on the existence of the conditions and individuals who may be involved in potential threats. Another critical element of the analytic process is to produce what is referred to as "actionable intelligence." Fundamentally, for intelligence to be useful it must provide direction for developing and executing plans. A law enforcement agency must be able to utilize intelligence products and develop activities or practices that prevent or mitigate the potential threat. An agency must be able to use the information in an operational manner. Moreover, actionable intelligence should ensure that the right information is placed into the hands of the right people who can influence a potential threat.

The next step of actionable intelligence is the provision of both tactical and strategic analysis. Depending on the type of threat, a wide range of tactical responses may be appropriate. Intelligence from tactical analysis overwhelmingly focuses on prevention where the use of information related to threats is utilized to develop strategies that will eliminate or mitigate shortterm and immediate threats (Kelling \& Bratton, 2006). Also, threats within a community typically change over time. Strategic analysis is primarily used longitudinally to plan and allocate resources in an attempt to understand the changing nature of a threat environment (Carter, 2009). Information is provided to decision makers about the changing nature, characteristics, and methodologies of threats and emerging threats for the purpose of developing response strategies and reallocating resources accordingly. When strategic analysis is used, plans may be developed to either prevent a threat from maturing or mitigate the threat should it emerge.

\section{Homeland Security Intelligence}

The Department of Homeland Security (DHS) demonstrated the importance of threat prevention beyond terrorism when the White House established the Homeland Security Presidential Directive-8 (HSPD-8), “...to prevent, respond to, and recover from threatened and 
actual domestic terrorist attacks, major disasters, and other emergencies...(U. S. Department of Homeland Security, 2003, p.h).” A salient component of this executive order focused on law enforcement personnel and what was determined to be their critical knowledge, skills, abilities and processes that were necessary for law enforcement and emergency services personnel to perform effective threat prevention. Such characteristics of law enforcement are referred to as capabilities. These capabilities have been articulated in detail within the Target Capabilities List (TCL) published in 2007 by DHS. Designed to protect the United States from all hazards, “...the TCL is a national-level, generic model of operationally ready capabilities defining allhazards preparedness" (U.S. Department of Homeland Security, 2007, 1). The list is divided into multiple sections associated with prevention and response. In the "Prevent Mission" section there are two specific law enforcement intelligence-related target capabilities: "Information Gathering and Recognition of Indicators and Warnings" and "Intelligence Analysis and Production" (U.S. Department of Homeland Security, 2007). Importantly, these developments created a new component of law enforcement intelligence that must be integrated into a contemporary form of intelligence practices known as "homeland security intelligence," which has been defined as...

...the collection and analysis of information concerned with non-criminal domestic threats to critical infrastructure, community health and public safety for the purpose of preventing the threat or mitigating the effects of the threat (Carter, 2009, 442).

These new intelligence responsibilities have emerged within the homeland security framework that intelligence activities at the state, local and conservation levels must assess threats posed by all-hazards. Given a significant continuum of potential threats that fall under the auspice of homeland security intelligence, the key challenge is for law enforcement agencies to focus on threats posed by hazards that have implications for public safety and order maintenance responsibilities in addition to criminal threats. Thus, another component entered into the intelligence equation. The most recent evolution of law enforcement intelligence related to the current discussion was the creation of the Information Sharing Environment (ISE) as required by the Intelligence Reform and Terrorism Prevention Act (IRTPA) of 2004. Despite the focus of this legislation on the federal Intelligence Community, nearly one-third of the actionable recommendations in the Information Sharing Environment Implementation Plan are directed toward state and local law enforcement.

The ISE seeks to "...implement an effective, widespread culture of information sharing, balanced with a need for security...” (Program Manager - Information Sharing Environment, 2007, 63). This plan provides a detailed process and action plan that indicate expectations for state and local law enforcement (to include conservation officers) to be participants in the ISE. The essence of information sharing and generation of raw information at the state, local, and conservation levels is intended to be via intelligence-led policing. Paramount to the current discussion is the importance of critical infrastructure protection. DHS identified five critical areas to be designated as law enforcement intelligence priorities - one of which is threats to the critical infrastructure and key resources (U.S. Department of Homeland Security, 2009). These threat assessments aim to define all hazard infrastructure risk for risk-based prioritization and decision making.

In the wake of 9/11, law enforcement has perhaps undergone the most dramatic overhaul of practices, policies and initiatives as compared to the rest of society. These changes are largely related to threat prevention and mitigation and the sharing of information and intelligence. Like many organizations of complex size and structure, these changes are still in the works and far 
from being implemented in many cases and in others are far from being effective. However, great strides have been gained by the majority of federal, state, and local policing agencies. Aiding their efforts has been an enormous amount of federal recommendations for best practices to help bridge the information gaps identified in the 9/11 Commission Report. The goal of this discussion is to identify a gap in homeland security information sharing an awareness that can best be filled by conservation officers as a result of their existing infrastructure and role within the U.S. law enforcement community. The practices emphasized in this discussion are informal and thus require minimal resource commitment while simultaneously yielding significant prevention results as well as professional collaboration.

\section{Community Partnerships}

The Heritage Report on Homeland Security proposes a number of empirically-based recommendations for keeping the nation safe from threats. The first recommendation focuses heavily on the role of community for both information collection and planning efforts (Heritage, 2002). The community, or jurisdiction area, is typically the primary and oftentimes first source of information as a result of their everyday interactions with their own environment. In some instances, the community is the only source of critical information. This can be likened to the force multiplier effect - the community acting as the "eyes and ears" of law enforcement. Policing agencies across the country have realized it is not a question of should the community be involved, but what is the best way to develop and nurture an effective partnership.

Community partnerships operate best when an educational or training program is provided from within the community (Heritage, 2002). In these instances, law enforcement personnel can use, for example, interactive and informal communication techniques to relay educational topics focused on different types of terrorism, indicators or terrorism planning, or suspicious activity. These sessions could also include an awareness component, since the community members attending the educational session are able to serve as "eyes and ears" for law enforcement. Awareness includes the ability to identify and observe suspicious activity, how to report it, and what will happen next. Community members must receive continuous feedback so they are aware about the extent to which their efforts are making an impact. Most importantly, these educational sessions must conclude with guiding information for the community members. Law enforcement must provide citizens with the ability to "follow-up" if they have questions after the session.

The majority of American law enforcement agencies already have experience - or at least a fundamental knowledge - developing relationships with the local community given the evolution of community-oriented policing over the past 20 years. Intelligence-led policing simply builds on the institutional structures already put in place by community policing to include a more preventive, threat-based approach to awareness. Community engagement is certainly not a new phenomenon for conservation officers, as they have been practicing these relationships for decades in the form of hunter education programs, forest fire prevention initiatives, and safety programs for off-road vehicles, boating, and snowmobiling. Intelligencebased information sharing builds on these already-cultivated skills practiced by conservation officers and enhances them to include a broader array of potential threats. 


\section{Public-Private Partnerships}

Similar to community partnerships, law enforcement has identified the need to develop partnerships with the private sector. Scholars traditionally examine these partnerships in the context of third-party policing (Mazerolle \& Ransley, 2005) or private security (Jones \& Newburn, 1998). However, scholars, law enforcement, and private sector businesses have begun to recognize the benefits involved with information sharing partnerships. Moreover, a demand for such partnerships was identified in the 9/11 Commission Report (National Commission on Terrorist Attacks upon the United States, 2004), the Government Accountability Office (government Accountability Office, 2007), the National Strategy for Homeland Security (Executive, 2002), the National Criminal Intelligence Sharing Plan (Global Intelligence Working Group, 2003), and the Fusion Center Guidelines (Global Intelligence Working Group, 2005).

Public-private partnerships work in a similar fashion to community partnerships, but tend to be more formal as a result of potential impacts to private company's bottom lines. More specifically, public-private partnerships rely on the same two-way communication and individual rapports among members, but they rely on formal memorandums of understanding that protect classified and proprietary information. These forms of partnerships can be characterized by their ongoing, trusting relationship between law enforcement and private entities for information sharing purposes with the goal of proactively identifying threats (Carter, 2009). Members from the private sector provide raw information, as well as analyzed intelligence products, to be included in the intelligence process while law enforcement members provide intelligence to the private sector on relevant threats. The identification of relevant threats is the product of the intelligence analysis process. This partnership model provides a road-map for basic implementation and the communication of information can be bi-directional where law enforcement is providing the private company with information to safeguard against threats to their business. For example, if a law enforcement agency becomes aware of an activist rally planned in protest of commercial fishing for shark fins, and has an established partnership with a commercial cruise line that operates out of the same port as the commercial fishermen, law enforcement can provide advanced information to the cruise company in the event the rally has an impact on the cruise company's day-to-day operations - and thus their financial bottom line. These relationships are commonly viewed in a "quid-pro-quo" fashion (Carter, 2008).

\section{Suspicious Activity Reporting}

All agencies - regardless of size or jurisdiction - have a role in the nationwide SAR Initiative (U.S. Department of Justice, 2009). The sharing of SAR information among local, state, and federal agencies is a critical element to prevent and mitigate attacks on American soil ranging from personal armed attack to biological terrorism. Suspicious activity reporting (SAR), known also as "tips and leads" (Carter, 2009), is an on-going initiative to identify, collect and manage information on suspicious behaviors and is being coordinated by the Global Intelligence Working Group, Program Manager's Information Sharing Environment, and the Intelligence and Analysis Directorate of the Department of Homeland Security. There are three types of SARs financial, all-crimes and information sharing environment. Financial SARs were initiated by the Bank Secrecy Act of 1970 in an effort to identify money laundering, racketeering and trafficking. All-crimes SARs are the most general and refer to any suspicious activity that can be related to any crime and is typically reported to a police officer. An example of an all-crimes SAR could 
be a community member witnessing someone in a ski-mask walking around a parking lot and checking car doors to see if they were locked. Information sharing environment SARs are concerned with suspicious behavior related to possible terrorist incidents. An example could be witnessing a person taking photographs of the structural areas of bridges or buildings (e.g., underneath a bridge where no "normal" pictures would be traditionally taken).

The third type of SAR is of great concern to state and local law enforcement; all-crimes SARs carry the most relevant information to law enforcement's day-to-day operations - this is consistent with the approach that could be taken by conservation officers as they attempt to address a range of criminal actives related to the natural environment. This is not to say state and local agencies do not accept or record financial or information sharing environment SARs because they do, but will typically move this information along to the proper jurisdiction or entity that could analyze the information as a host of state, local, and even federal organizations have SAR processing responsibilities.

\section{AN EMERGING BIOLOGICAL TERRORISM THREAT}

The Centers for Disease Control and Prevention (CDC) defines biological terrorism as a planned release of viruses, germs or toxins in order to harm or kill citizens and that likely modes of transmission include aerosol, food, water or insects (U.S. Department of Health and Human Services, 2001). Bioterrorism commonly focuses on the dispersion of biological agents intended to harm citizens, such as anthrax. However, individuals who aim to use biological species as a method of attack have largely gone unrecognized by the DHS, the CDC, or any other organization tasked with threat prevention and mitigation. It is perhaps best to keep in mind key factors that determine what incidents are considered terrorism. There is no specific definition of a terrorist act, however a recent congressional report identified terrorist acts as involving the use, or threat of use, of any method of attack that is driven by an ideological motivation (Bjelopera, 2013). The use of biological species as a method of terrorist attack was specifically mentioned in this report as an emerging likelihood to be utilized by animal rights extremists and environmental extremists.

The introduction of an invasive species into an environment unnatural to that species with the intent to do biological harm to the environment is an emerging form of bioterrorism. Invasive, or alien or exotic, species are characterized by being aggressive, prolific breeders, and rapid disperses. Invasive species out-compete native species, can introduce parasites and/or disease, prey on native species, can adversely alter habitat, and pose significant ecological and economic consequences (McConnell \& Abel, 2008). Many examples exist that scholars have identified as posing threats to humans and our economy. Feral pigs can be used to carry the Nipah virus and spread disease to humans and wildlife. Striga is a plant parasite that can destroy corn crops and subsequently devastate agricultural commodity markets and bio-fuel production. The heartwater pathogen, a microbe that can cause heart and pulmonary edema, is carried by the tropical bont-tick and can kill large mammals, other wildlife, and can potentially be transmitted to humans. Lastly, barberry plants are frequently eaten by a variety of birds whose droppings spread wheat stem rust which can cause a decline or destruction of wheat production (Heather and Hallman, 2007).

Precedent of such examples include the invasion of multiple aquatic species in San Francisco Bay in the late 1980s, such as the invasive clam species from Asia called 
Potamocorbula Amurinsis and in the 1990s an extremely prolific aquatic weed native to Asia, known as hydilla, interfered with water usage, displaces native species, and impacted local fishing economies (Pratt, 2003). Across California in 1990, the glassy winged sharpshooter which hosts the bacterium Xylella Fastidiosa - caused Pierce's Disease in grapes, which infects and kills the grape vine. Severe outbreaks of the disease necessitated destruction of diseased plants and a major replanting of grape vines, resulting in a reduction in grape production and a 40 million dollar lost to the grape-related industries in California (Souder, 2000).

Bioterrorism, closest resembling that of environmental terrorism or warfare (Schofield, 1999), creates a significant threat to the United States homeland. Such threats pose a significant challenge to our defense mechanisms and provide a unique and well-suited opportunity for conservation officers to enhance homeland security efforts. The following case study is provided to serve as an example of how an invasive species can be used as a method of terrorism. It is not provided to be analyzed as a table-top exercise or an instance in which specific action-steps for improvement can be identified. As noted by a leading expert in the field and National Guard Colonel Robert J. Pratt (2004), “Terrorist adversaries will not overlook the overwhelming impact that invasive species could have on the United States” (p. 47).

\section{Zebra Mussels as a Terrorist Threat}

The following case study example was identified through a Department of Homeland Security-funded grant project. Because the investigation is on-going, no unique identifiers are presented. Zebra mussels (Dreissena Polymorpha) are native to Eurasia and are considered to be "invasive" outside their normal range. In 1988 they were introduced into the Midwestern U.S.'s Lake St. Clair through ballast water discharged from a transoceanic vessel (Southeast Ecological Science Center, 2012). Zebra mussels grow in dense clusters and are known for clogging pipes, valves, and drains that affect drinking water, hydroelectric plants, and manufacturing firms (O’Neill, Jr., 1993). The animals are relatively small and easily transported by most any kind of container such as a plastic bag, jar, or bucket. They can survive out of the water for several days in cool, humid conditions by tightly closing their shell (O’Neill, Jr., 1993). Zebra mussels impose significant negative effects on the ecosystems they inhabit and represent one of the most important biological invasions into North America in recent time (Pace et al., 1998).

Economic impacts of zebra mussels have not been examined in detail since the mid1990s, although predictions have ranged as high as \$1 billion per year (Connelly et al., 2007; Pimentel, 2005). Moreover, the over-land transportation of boats, motors, and trailers poses one of the greatest risks for spreading zebra mussels as larger mussels can live out of water for up to three days. The discussion to this point has demonstrated the potential negative impact zebra mussels can have on American society - from recreational to ecological to economic. Until recently, these potential consequences were credited by natural resource, utility, and other decision-makers to natural or unintended progression across aquatic ecosystems. This way of thinking was challenged when an individual publically threatened to purposefully deploy zebra mussels as a method of terrorism. A Congressman from a Midwestern state was a vocal supporter of legislation to ban Internet gaming in the U.S. An individual who opposed this legislation made a threat to the Congressman's office that if the Congressman voted in favor of the Internet gaming ban, the individual would purposefully introduce zebra mussels into the freshwater lakes within the Congressman's home state that were, at the time, un-infested. The Congressman subsequently voted for the ban on Internet gaming. At the time of this article, zebra mussels have since appeared in lakes within the Congressman's state. 
Ecologists consider zebra mussels to be highly invasive. Between 1998 and 2007, 23 U.S. states and 2 Canadian Provinces were invaded, as were all 5 of the Great Lakes, inland lakes in 9 states and 21 rivers. Ecologists speculate the mussels will continue to spread into additional rivers and inland lakes that are currently uninfected but within range of the invasion based on environmental and geological variables. Connelly et al. (2007) surveyed water treatment facilities within known zebra mussel range and reported that respondents thought zebra mussels had been in the facility for 6 months to 1 year before discovery; only 20\% of responding facilities had preventative measures in place prior to the discovery of zebra mussels. Given the ecological and human dimensions of zebra mussel invasions and management, it is possible that zebra mussels appeared in the case study lake as part of the "natural" ecological invasion of mussels through the Midwest and that the officials were not aware of the mussel invasion because, like Connelly et al. (2007) found, they were not actively looking for them. Officials only searched for the mussels after the threat was made. Regardless of when or how the zebra mussels arrived in the case study lake, the fact that a bioterrorist threat was made by a constituent in response to an impending policy decision illustrates that there were no biosecurity safeguards in place at the time. Thus, the possibility of such a threat is extremely viable as is our nation's vulnerability to such a threat in the future.

Zebra mussels are explicitly included in the United States Code 42 USC 42 and 43 - also known as the Lacey Act. Under this code, the transportation of zebra mussels is a federal misdemeanor (U.S. Fish and Wildlife Service, 2012). If an individual intentionally causes damage or loss of property as a result of the purposeful introduction of zebra mussels, or conspires to do so, this can be classified under the federal crime of Animal Enterprise Terrorism which is punishable as a felony depending on the value of property loss (Congress, 2006). Thus, the threat of introducing an invasive species into a freshwater ecosystem represents a felony and this act serves as a legislative tool to criminally prosecute violators. Furthermore, if such an act is determined to be motivated by an ideological purpose (e.g. Animal Liberation Front or Environmental Liberation Front), it can be classified as an act of domestic terrorism (Bjelopera, 2013).

To provide further context of biological threats, an example of a more method of utilizing biological agents as a threat is provided. While conservation officers should not be synonymous with rural America, they spend a majority of their time in rural areas in proportion to traditional local or state law enforcement. Within rural America is where most of the country's cattle industry can be found. Foot and mouth disease (aphthovirus), a highly infectious disease that infects cloven-hoofed animals and holds potential harm to both human health as well as key resources in the United States. For example, in Dodge City, Kansas, the cattle industry represents a $\$ 500,000$ per day key resource for the region in which the vast majority of jobs and local capital rely on this industry (Carter, 2009). The foot and mouth disease struck Britain in 2001 with a vengeance, killing over a thousand livestock (Cameron \& Pate, 2003) with millions more voluntarily killed or destroyed to prevent the spread of the disease (Leatherbury, 2003). Furthermore, to prevent the disease from spreading from Great Britain, the European Union placed an embargo on British meat. In turn, the United States placed a temporary ban on meat imports from the entire European Union and Chile. To control the spread of the disease in Britain, limits were placed on movement of people and equipment throughout the area. Overall, foot and mouth disease cost British companies 30 billion dollars, with a 300,000 dollar average loss to large businesses and a 75,000 dollar loss to small businesses (Pratt, 2004). If such a disease were used as a biological attack in Dodge City, Kansas, there would not only be a 
significant impact on the regional economy, but also a ripple effect on the beef industry across the entire U.S. - not to mention health risks across the U.S. for those who could consume the infected meat.

The zebra mussel case study, as well as the foot and mouth disease example, demonstrates the implications for all-threats, all-hazards homeland security and as such, necessary action steps must be taken to learn from this event. The application of information sharing practices implemented by state and local law enforcement serve as an appropriate foundation on which these necessary action steps can be based.

\section{DISCUSSION}

A significant characteristic of a successful intelligence-led policing approach to threat prevention and mitigation is the reliance on informal relationships to increase information sharing. Although these relationships can be as simple as a police officer and conservation officer meeting for coffee at the same place in the morning and letting one another know what has been going on in their respective patrol areas, they often provide the circumstance by which a threat comes to law enforcement's attention. Moreover, as conservation officers continue to enhance community awareness of suspicious activity the more the odds of preventing crimes and threats shifts to their advantage. A more formal approach to information sharing would involve communication between conservation departments and state fusion centers. As intelligence-led policing relies on the analysis of information, fusion centers serve as a viable mechanism by which conservation and law enforcement can both benefit. Formal communication channels usually take the form of an electronic information sharing system (such as the Regional Information Sharing System or the Homeland Security Information Network) and provide realtime access to threats and crime trends in specific geographic areas.

As in the case study of zebra mussels discussed herein, threats to homeland security can have many faces and a wide range of intentions. Increased awareness to identify possible threats and/or persons involved in threats could help thwart the spread of invasive species such as zebra mussels. For example, conservations officers can educate the boating community about how to identify zebra mussels on boats or in live wells that are going in and out of different water systems. Not only will a more open dialogue between law enforcement and the community aid in the prevention of spreading invasive species, but it also allows conservation officers to track such spreading if it does occur and gather information that may better inform their efforts to prevent or mitigate potential negative impacts. Lastly, conservations officers can better explore the benefits of developing partnerships with the private sector - specifically organizations that suffer financial damage from invasive species such as hydroelectric plants - to not only create opportunities for two-way information flow, but also perhaps opportunities to gain more resources. For example, if a hydroelectric company is spending two million dollars annually combating the spread of zebra mussels that are clogging their water intake pipes, it could be beneficial to spend a fraction of that money towards a preventive partnership that could mitigate the problem.

Specific recommendations for policy and "action-steps" to guide those tasked with carrying out this integration are sorely needed. However, given space considerations and the litany of variations these recommendations could take across the fragmented law enforcement structure within the U.S., such a discussion is beyond the scope of the present study. Similar to 
traditional law enforcement agencies, conservation agencies are tasked with a variety of responsibilities and jurisdictional differences depending on their location and constituents. Studies examining law enforcement homeland security preparedness have found that even small agencies in close proximity to a major urban area are going to have advanced functions due to risks associated with major urban areas (Schafer et al., 2009). The same holds true for conservation agencies. For example, a conservation agency located (or operating) near Detroit, Michigan is likely engaged in suspicious activity reporting along the waterways given Detroit's status as a major urban area under the Urban Area Security Imitative (UASI) as well as the city's proximity along the U.S.-Canada border. In contrast, many other conservation agencies in rural areas that may have the same demographics as an agency near a major urban area are not likely to be engaged in suspicious activity reporting. A comprehensive discussion as to how varying conservation agencies can integrate an intelligence-led approach and enhance the homeland security mission is needed to both advance research as well as inform professionals tasked with this responsibility.

Furthermore, as it has been discussed throughout this article, homeland security efforts are in a position to capitalize on an existing rural American infrastructure already established by conservation officers throughout the United States. By utilizing initiatives that are inexpensive and based primarily on informal information sharing and awareness programs, conservation officers and the rest of the law enforcement community can increase the flow of raw information, increase citizen awareness, increase inter-jurisdictional collaboration for a variety of crime and threat problems, increase preparedness, mitigation, and response capabilities while continuing to decrease America's vulnerability to a wide range of threats. Such an enhancement for preparedness is also cost effective as little resources are likely needed to integrate conversation officers into the homeland security role. No additional hardware or resources are needed to fulfill this capacity aside from training and educating conservation personnel on what to be aware of and how to report and respond to suspicious activities.

Lastly, there is a significant need for future research to be focused on the issues presented. As was noted, the existing knowledgebase regarding conservation officers' roles, responsibilities, and activities is largely unexplored within academic literature. Scholars need to examine the national framework of conservation officers as it applies to their general functions. A host of similar research exists related to state and local law enforcement. For example, the Law Enforcement Management and Administrative Statistics (LEMAS) survey conducted by the Bureau of Justice Statistics, U.S. Department of Justice occurs every four years with a national sample to examine multiple constructs related to the tasks, resources, and organizational characteristics of state and local police. Though conservation officers are largely considered to be state law enforcement officers, conservation agencies are not included in the LEMAS survey. Such an assessment specifically for conservation departments every four years is likely unnecessary, yet a similar national survey would help to illustrate the current conservation officer environment in the U.S. and would enhance the ability of scholars to provide context and empirical validation to their research while simultaneously using evidence to inform policy decisions. 


\section{Notes}

1. Examples of biological species include Feral pigs can be used to carry the Nipah virus and spread disease to humans, cattle and wildlife; the Heartwater pathogen, a microbe that can cause heart and pulmonary edema, and carried by the tropical bont tick, can kill deer, cattle or other wildlife, and potentially be transmitted to humans; the Striga, a plant parasite that can destroy corn crops, and subsequently devastate commodity markets and bio-fuel production, and Barberry plants that are eaten by birds whose droppings spread wheat stem rust, which can cause a decline or destruction of wheat production (Roberge, 2012).

2. These districts are commonly referred to as one of the following: Land Conservation Departments, Natural Resource Conservation Districts, Natural Resources Districts, Resource Conservation Districts, Soil Conservation Districts, or Soil \& Water Conservation Districts.

3. 28 Code of Federal Regulations (CFR) Part 23 is a guideline for law enforcement agencies. It contains implementing standards for operating federally grant-funded multijurisdictional criminal intelligence systems. It specifically provides guidance in five primary areas: submission and entry of criminal intelligence information, security, inquiry, dissemination, and the review-and-purge process (Institute for Intergovernmental Research, 2009). 


\section{REFERENCES}

Bjelopera, J. (2013). The Domestic Terrorist Threat: Background and Issues for Congress. Congressional Research Service. Washington, D.C. R42536. Retrieved from http://www.fas.org/sgp/crs/terror/R42536.pdf

Cameron, G. (1999.) Nuclear Terrorism: A Threat Assessment for the 21st Century. New York: St. Martin's.

Cameron, G. \& Pate, J. (2003). Covert Biological Weapons Attacks Against Agriculture Targets, Assessing the Impact Against U.S. Agriculture. In R. D. Howard, R. L. Sawyer, \& B. R. McCaffrey (Eds.) Terrorism and Counterterrorism: Understanding the New Security Environment. Guilfford, CT: McGraw Hill.

Carter, D. L. (2009). Law Enforcement Intelligence: A Guide for State, Local and Tribal Law Enforcement Agencies. Second Edition. Washington, DC. U.S. Department of Justice, Office of Community Oriented Policing Services.

Carter, D. L. \& Carter, J. G. 2009. Intelligence led policing: Conceptual considerations for public policy. Criminal Justice Policy Review, 20(3), 310-325.

Carter, J. G. 2008. The structure and function of public-private partnerships for Homeland Security. The Homeland Security Review: A Journal of the Institute for Law and Public Policy, 2(3), 235-251.

Carter, J. G. \& Rip, M. (Online First). Homeland security and public health: A critical integration. Criminal Justice Policy Review. First published online August 28, 2012. DOI:10.1177/0887403412452425

Congress. (006. Animal Enterprise Terrorism Act. Congressional Record, 152. Washington. DC. Legislative History.

Connelly, N. A., O'Neil, C. R., Knuth, B. A., \& Brown, T. L. (2007). Economic impacts of zebra mussels on drinking water treatment and electric power generation facilities. Environmental Management, 40, 105-112.

Crelinsten, R. D. 1999. Terrorism and counter-terrorism in a multi-centric world: Challenges and opportunities. Terrorism and Political Violence, 11(4), 170-196.

Damphousse, K. R., Smith, B. L. \& Sellers, A. (2003). The targets and intended victims of terrorist activities in the United States. In D. Das and P. C. Kratcoski (Eds.). Meeting the Challenges of Global Terrorism, 171-187. Lanham, MD. Lexington Books.

Eliason, S. L. (2007). From wildlife specialist to police generalist. Southwest Journal of Criminal Justice, 4(2), 120-132.

Eller, W. L. (2010). Leveraging Rural America in the Fight Against Terrorism in America Through the Use of Conservation Districts. A Masters Thesis. Monterey, CA. Naval Post Graduate School.

Executive Office of the President. (2002). National Strategy for Homeland Security. Washington, DC.

Falcone, D. (2004). America's conservation police: Agencies in transition. Policing: An International Journal of Police Strategies \& Management, 27(1), 56-66.

Global Intelligence Working Group. (2003). National Criminal Intelligence Sharing Plan. Washington, DC. Bureau of Justice Assistance, Bureau of Justice Programs, U.S. Department of Justice. 
Global Intelligence Working Group. (2005). Guidelines for establishing and operating fusion centers at the local, state, tribal and federal level. Washington, DC. U.S. Department of Homeland Security.

Gore, M. L. (2011). The science of conservation crime. Conservation Biology. 25(4), 659-661.

Heather, N. \& Hallman, G. J. (2007). Agricultural Warfare and Bioterrorism using Invasive Species. In N. Heather \& G. Hallman (Eds.), Pest Management and Phytosanitary Trade Barriers, 14-19. Wallingford, UK: CAB International.

Heritage Foundation. (2002). Defending the American Homeland. A Report of The Heritage Foundation Homeland Security Task Force. Washington, DC.

Institute for Intergovernmental Research. (2009). 28 CFR Part 23: Overview. Retrieved from: http://www.iir.com/28CFR/Overview.htm

International Association of Chiefs of Police. (2002). Criminal intelligence sharing: A national plan for intelligence-led policing at the local, state and federal levels. Recommendations from the Intelligence Summit. Retrieved from http://epic.org/privacy/fusion/intelsharerpt.pdf

Jones, T. \& Newburn, T. (1998). Private Security and Public Policing. Oxford University Press.

Kelling, G. L., \& Bratton, W. J. (2006). Policing terrorism. Civic Bulletin, 15(12).

Kronin, A. K. (2003). Terrorist motivations for chemical and biological weapons use: Placing the threat in context. Washington, DC. Congressional Research Services.

Leatherbury, J. (2003). Living through the FMD outbreak. Country Spirit, 1, 13-20.

Mazerolle, L. \& Ransley, J. (2005). Third Party Policing. Cambridge, UK. Cambridge University Press.

McConnell, R. L., \& Abel, D. C. (2008). Environmental Issues: an introduction to sustainability. Third Edition. Upper Saddle River, New Jersey: Pearson Prentice Hall.

McGarrell, E. F., Freilich, J. D. \& Chermak, S. (2007). Intelligence-led policing as a framework for responding to terrorism. Journal of Contemporary Criminal Justice, 23(2), 142-158.

Missouri Department of Conservation. (2012). Zebra Mussel Control. Invasive Animal Management. Retrieved from http://mdc.mo.gov/landwater-care/invasivespecies/invasive-animal-management/zebra-mussel-control

National Association of Conservation Districts. (2012). About Conservation Districts. Retrieved from: http://nacdnet.org/about/districts/index.phtml

National Commission on Terrorist Attacks upon the United States. (2004). 9/11 Commission Final Report. Washington, DC.

North East Conservation Law Enforcement Chiefs Association. (2013). Who We Are. Retrieved from http://www.necleca.org/NECLECA/Who_we_are.html

O’Neill, Jr., C. (1993). Control of Zebra Mussels in Residential Water Systems. Sea Grant: Coastal Resources Fact Sheet. Retrieved from http://library.marist.edu/diglib/EnvSci/archives/alienspe/oneillcontrol/o'neill\%20\%20control\%20of\%20zebra\%20mussels\%20in\%20residential\%20water\%20systems.htm 1

Pace, M. L., Findlay, S. E. G. \& Fischer, D. (1998). Effects of an invasive bivalve on the zooplankton community of the Hudson River. Freshwater Biology, 39, 103-116.

Parachini, J. V. (2001). Comparing motives and outcomes of mass casualty terrorism involving conventional and unconventional weapons, Studies in Conflict and Terrorism, 24(5), 389406. 
Pimentel, D. (2005). Aquatic nuisance species in the New York State Canal and Hudson River Systems and the Great Lakes Basin: An economic and environmental assessment. Environmental Management, 35, 692-701.

Pratt, R. J. (2004). Invasive threats to the American homeland. Parameters, 1, 44-61.

Pratt, R. J. (2003). Invasive Species - A Threat to the Homeland? Strategy Research Project. U.S. Army War College. U.S. Department of Defense. Retrieved from http://www.dtic.mil/cgi-bin/GetTRDoc?AD=ADA415732

Program Manager for Information Sharing Environment. (2007). Implementation Plan. Retrieved from http://www.ise.gov/docs/eaf/ISE-EAF_v1.0_20070830.pdf

Ratcliffe, J. H. (2008). Intelligence-Led Policing. Cullompton. Willan Publishing.

Roberge, L. (2012). Are Terrorists Using Invasive Species As Biological Weapons? Retrieved from http://beforeitsnews.com/story/1706/298/Are_Terrorists_Using_Invasive_Species_As_Bi ological_Weapons.html

Rotz, L. D., Khan, A. S., Lillibridge, S. R., Ostroff, S. M. \& Hughes, J. M. (2002). Public Health Assessment of Potential Biological Terrorism Agents, Emerging Infectious Diseases, 8(2), 225-230.

Schafer, J. A., Burruss, G. W., \& Giblin, M. J. (2009). Measuring homeland security innovation in small municipal agencies: Policing in a post 9/11 world. Police Quarterly, 12, 263288.

Schofield, T. (1999). The environment as an ideological weapon: a proposal to criminalize environmental terrorism. Boston College Environmental Affairs Law Review, 26, 619647.

Shea, D. A. (2004). Terrorism: Background on Chemical, Biological, and Toxin Weapons and Options for Lessening Their Impact. Washington, DC. Congressional Research Services.

Souder, M. (2000). Small carriers deliver big worries to local agriculture. Farm Bureau Bulletin, 29(4), 1-2.

Southeast Ecological Science Center. (2012). Frequently Asked Questions about the Zebra Mussel. $\quad$ Retrieved from http://fl.biology.usgs.gov/Nonindigenous_Species/Zebra_mussel_FAQs/zebra_mussel_fa qs.html

State of Connecticut. (2013). Connecticut Environmental Conservation Police Officers What We Do. Department of Energy and Environmental Protection. Retrieved from http://www.ct.gov/deep/cwp/view.asp?A=2695\&Q=322624

U.S. Census Bureau. (2002). Measuring America: The Decennial Censuses From 1790 to 2000. Washington, DC: U.S. Census Bureau. Retrieved from http://www.census.gov/prod/2002pubs/pol02marv.pdf.

U.S. Department of Health and Human Services. (2001). The Public Health Response to Biological and Chemical Terrorism. Washington, DC. Centers for Disease Control and Prevention.

Retrieved

from http://emergency.cdc.gov/Documents/Planning/PlanningGuidance.PDF

U.S. Department of Homeland Security. (2009). Homeland Security Intelligence Analytic Priorities. Office of Intelligence and Analysis. Washington, DC. Retrieved from: http://www.dhs.gov/xabout/structure/gc_1220886590914.shtm

U.S. Department of Homeland Security. (2007). Targeted Capabilities List. Retrieved from https://www.llis.dhs.gov/displayContent?contentID=26724 
U.S. Department of Homeland Security. (2005). Interim National Preparedness Goal. Homeland Security Presidential Directive 8: National Preparedness. Washington, DC. Retrieved from http://www.oregon.gov/OMD/OEM/docs/dom_prep/fed_support/interim_national_prepar edness_goal.pdf?ga $=\mathrm{t}$

U.S. Department of Homeland Security. (2003). Homeland Security Presidential Directive-8. Retrieved from http://www.dhs.gov/xabout/laws/gc_1215444247124.shtm\#1

U.S. Department of Justice. (2009). Nationwide Suspicious Activity Reporting (SAR) Initiative. Washington, DC. Bureau of Justice Assistance.

U.S. Department of Justice. (2007). Intelligence-led policing and the Bureau of Justice. Washington D.C. Bureau of Justice Assistance.

U.S. Fish and Wildlife Service. (2012). 18 USC 42-43, 16 USC 3371-3378, Lacy Act. Washington, DC. Office of Law Enforcement. Retrieved from http://www.fws.gov/le/pdffiles/Lacey.pdf

Waeckerle, J. F. (2000). Domestic Preparedness for Events Involving Weapons of Mass Destruction. The Journal of the American Medical Association, 283, 252-254.

Weiss, A. (1998). Informal Information Sharing Among Police Agencies. Washington, DC. National Institute of Justice. 